\title{
GENETIC SIMILARITY OF BRAZILIAN HULL-LESS AND MALTING BARLEY VARIETIES EVALUATED BY RAPD MARKERS
}

\author{
Mariela Aparecida Kroth; Micheline Sandra Ramella; Caroline Tagliari; Alicia de Francisco; \\ Ana Carolina Maisonnave Arisi* \\ UFSC/CCA - Depto. de Ciência e Tecnologia de Alimentos, Rod. Admar Gonzaga, 1346 - 880034-001 - \\ Florianópolis, SC - Brasil \\ *Corresponding author<arisi@cca.ufsc.br>
}

\begin{abstract}
Barley (Hordeum vulgare L.) is widely used for brewing and animal feed. Recently, it has become desirable for human consumption due to its high nutritional significance, specially hull-less or naked barley. There are differences in nutritional and malting characteristics among barley varieties. RAPD procedure is able to separate barley varieties at various similarity levels. The aim of this work was the RAPD analysis of six Brazilian hull-less varieties and seven malting varieties. PCR reactions were performed with eleven random primers. A total of 34 RAPD fragments was obtained with five primers. A dendrogram was constructed based on the Jaccard similarity coefficient. Barley varieties displayed an average similarity coefficient of 0.53. Intravarietal monomorphic fragments allowed differentiation among varieties. The averages of intravarietal similarity coefficients ranged from 0.53 to 0.85 . RAPD markers, detected in this work, were suitable for differentiation among Brazilian barley varieties.
\end{abstract}

Key words: Hordeum vulgare, polymorphism, molecular characterization

\section{SIMILARIDADE GENÉTICA DE VARIEDADES BRASILEIRAS DE CEVADA NUA E CEVADA CERVEJEIRA AVALIADA POR MARCADORES RAPD}

\begin{abstract}
RESUMO: A cevada (Hordeum vulgare L.) é amplamente empregada na produção de cerveja e na ração animal. Recentemente, este cereal tornou-se desejável na alimentação humana devido ao seu alto valor nutricional, principalmente da cevada nua ou sem casca. Existem diferenças nas características nutricionais e para malteação entre as diversas variedades de cevada. O procedimento RAPD é capaz de separar as variedades de cevada em vários níveis de similaridade. O objetivo desse trabalho foi analisar por RAPD seis variedades brasileiras de cevada nua e sete variedades de cevada cervejeira. Reações de PCR foram realizadas com onze iniciadores aleatórios. Um total de 34 fragmentos de amplificação foi obtido com cinco destes iniciadores. Baseado no coeficiente de similaridade de Jaccard, um dendrograma foi construído. As variedades de cevada apresentaram índice médio de similaridade de 0,53. Fragmentos monomórficos intravariedades permitiram a diferenciação entre as variedades. Os coeficientes médios de similaridade intravariedades encontram-se entre 0,53 e 0,85 . Os marcadores RAPD detectados neste trabalho foram adequados para a diferenciação entre as variedades brasileiras de cevada.

Palavras chave: Hordeum vulgare, polimorfismo, caracterização molecular
\end{abstract}

\section{INTRODUCTION}

Barley (Hordeum vulgare L) is a potentially useful grain for different purposes. It is widely used for brewing and for animal feed. In Asian countries, barley has multiple uses in the food industry (Bhatty \& Rossnagel, 1998). Due to its high soluble fiber content and nutritional significance, barley has become a desirable grain for human consumption, specially hull-less (or naked) varieties with high $\beta$-glucan content (Bathy, 1999; Gill et al., 2002). Otherwise, hull-less varieties with low $\beta$-glucan content are foraged for their low viscosity (Yu et al.,
2003). Malting varieties are preferred by brewing industries since the hull forms a filter bed during wort filtration, although hull-less barley could be also employed in malting (Bhatty, 1999).

There is a vast number of barley varieties with significant differences in malting and nutritional characteristics (Yu et al., 2003; Selbach \& Cavalli-Molina, 2000; Bhatty, 1999; Molina-Cano et al., 1997; Tsuchiya et al., 1995). Genetic analysis with RAPD markers is relatively easy, fast and efficient, therefore it has been extensively used to determine genetic diversity among barley varieties and to identify the best quality ones for malting 
(Todorovska et al., 2003; Diaz-Perales et al., 2002; Fernandez et al., 2002; Hang et al., 2000; Selbach \& Cavalli-Molina, 2000; Baum et al., 2000). Nevertheless, there are few studies about genetic characterization of hull-less barley (Yu et al., 2002).

In order to explore areas of application for Brazilian hull-less varieties, which are still in developmental stages and not commercially available, RAPD analysis were conducted with these varieties and also with malting varieties for comparison purposes. In this work, we used RAPD markers to evaluate the genetic similarity among and within thirteen Brazilian barley varieties (six hull-less and seven malting varieties) and one North American malting variety.

\section{MATERIAL AND METHODS}

Seeds from six Brazilian hull-less barley varieties, seven Brazilian and one North American malting varieties (Harrington) were used for RAPD characterization (Table 1). Seeds of seven to ten plants from each variety were germinated in the greenhouse and DNA was isolated from leaves $(400 \mathrm{mg}$ ) of individual 20-day-old plants using the procedure of Doyle \& Doyle (1990).

The PCR reaction mixture $(25 \mu \mathrm{L})$ contained approximately $50 \mathrm{ng}$ of barley DNA, $0.5 \mu \mathrm{M}$ of primer (InVitroGene), $0.2 \mathrm{mM}$ of each dNTP, $10 \mathrm{mM}$ Tris- $\mathrm{HCl}$ (pH 8.0), $50 \mathrm{mM} \mathrm{KCl}, 2 \mathrm{mM} \mathrm{MgCl}{ }_{2}$ and $1 \mathrm{U}$ of Taq DNA polymerase (Invitrogen). PCR reactions were performed in thermal cycler (MiniCycler ${ }^{\mathrm{TM}} \mathrm{MJ}$ Research) programmed for $94^{\circ} \mathrm{C}$ for $2 \mathrm{~min}$., 44 cycles of $94^{\circ} \mathrm{C}$ for 1 min., $36^{\circ} \mathrm{C}$ for $30 \mathrm{sec} ., 72^{\circ} \mathrm{C}$ for $2 \mathrm{~min}$., and finally $72^{\circ} \mathrm{C}$ for $7 \mathrm{~min}$. Eleven primers were used to generate RAPD fragments (A01, A02, A03, F03, F04, F05, F07, F08, F09, F11, F15). DNA amplification fragments were separated on $1.5 \%$ agarose gel, stained with ethidium bromide and photographed under ultraviolet light with a digital photosystem. DNA fragments length was estimated by comparison with $1 \mathrm{~kb}$ ladder (Amershan).

DNA bands were scored as present (1) or absent (0) to construct a binary matrix in order to determine

Table 1 - Barley cultivars.

\begin{tabular}{ll}
\hline Malting & \multicolumn{1}{c}{ Hull-less } \\
\hline BR-2 & IAPAR 39 \\
EMBRAPA127 & IAC8501/22 \\
EMBRAPA 128 & IAC8501/31 \\
CBB1 & IAC8501/12 \\
BRS 195 & IACIBON214/82 \\
MN 684 & IAC8612/421 \\
MN 698 & \\
HARRINGTON & \\
\hline
\end{tabular}

Jaccard similarity coefficient. Comparison among the individuals of the same variety was performed to evaluate the intravarietal relationships using each individual as an OTU (operational taxonomic unit). The different varieties were compared by monomorphic bands displayed by all individuals of each variety in order to evaluate the intervarietal relationships. Data analysis was performed with the NTSYS program version 2.02 (Rohlf, 1992). Dendrogram using each variety as an OTU was constructed from the Jaccard similarity coefficient data by the UPGMA clustering method to evaluate the intervarietal relationships. Genetic similarity and polymorphic band percentage were estimated.

\section{RESULTS AND DISCUSSION}

Among the eleven primers used to amplify DNA, five yielded scorable fragments. Further RAPD analysis was based on reproducible fragments obtained with the DNA amplification of 137 plants from thirteen varieties, with a minimum of seven plants per variety. Examples of RAPD profiles are in Figure 1. Faint bands were not considered because of their ambiguous nature.

Five primers produced a total of 34 reproducible bands, with DNA fragment sizes ranging from 300 to $4400 \mathrm{bp}$. All of them were polymorphic (Table 2). High levels of polymorphic RAPD fragments were also observed by other authors for Brazilian (93\%; Selbach \& Cavalli-Molina, 2000) and Chinese varieties (77\%; Chen et al., 2000). The total number of reproducible bands generated per primer per individual varied from 2 to 12 , with an average of 6.8 bands per primer. Monomorphic bands were detected within each variety, thus they were considered as marker bands that allowed differentiation between varieties. A total of 31 marker bands were identified, each primer generated on average 6.2 marker bands per primer (Table 2).

Cluster analysis from genetic similarity values was conducted to generate a dendrogram indicating relationship among the thirteen Brazilian varieties and one

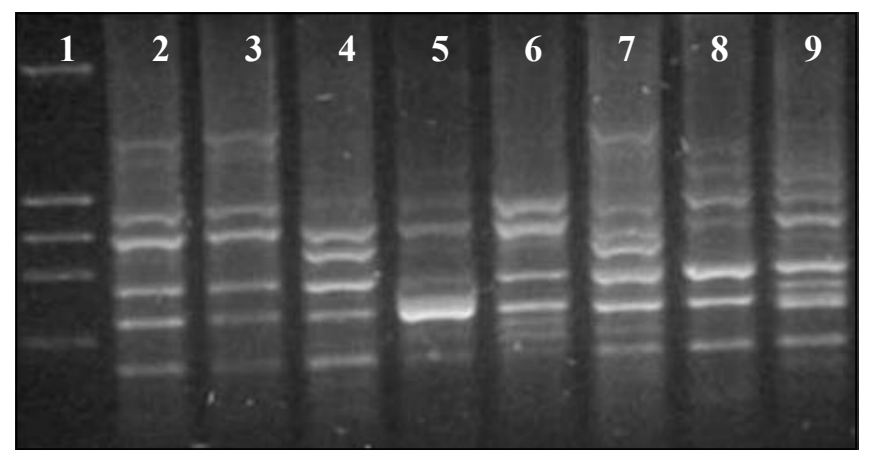

Figure 1 - RAPD fragments generated by primer F09. Lane 1: DNA $1 \mathrm{~kb}$ ladder, lanes 2-9: Eight individual plants from variety IACIBON 214/82. 
North American variety (Figure 2). Jaccard similarity coefficient was used because it does not consider absence of bands as a similarity. Varieties BR-2, CBB1, BRS 195, MN 684, HARRINGTON, IAC 8501-31, IACIBON 214/ 82, IAC 86012/421 and EMBRAPA 127 were closely related with similarity coefficients higher than 0.75 . Varieties IAC 8501/12 and IAPAR 39 showed similarity coefficients of approximately 0.70 with the group of varieties above-mentioned. Low similarity coefficients $(0.40-$ 0.50) were observed among varieties MN 698, EMBRAPA 128, IAC 8501/22 and the others (Figure 2). The grouping method did not separate malting from hullless varieties.

The intervarietal similarities of each variety with all others were calculated by the Jaccard similarity coefficient and the mean similarity coefficient among all varieties was 0.53 , very close to 0.52 previously reported by Selbach \& Cavalli-Molina, (2000), who affirm that Brazilian varieties show high degree of genetic relationship. Because barley is a self-pollinating plant, its heterozigosity level is not as high as that of cross-pollinating plants. Therefore, numerous varieties were collected to increase the breeding background. In contrast, most current breeding efforts in barley involve crosses among elite lines that share common ancestors (DiazPerales et al., 2002; Yu et al., 2002; Todorovska et al.,
2003). Brazilian barley varieties emerged from common ancestors and it could explain the high degree of genetic similarity among them.

Similarity coefficients among individuals of each variety are shown in Table 3 . The average of intravarietal similarity ranged from 0.53 to 0.85 . Again, these values were very close to those reported by Selbach \& CavalliMolina (2000). Hull-less varieties presented high simi-

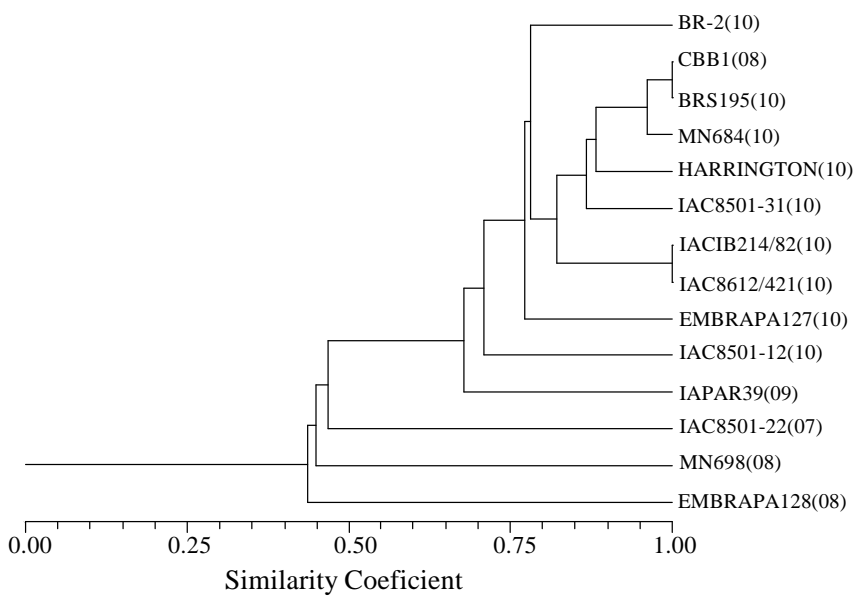

Figure 2 - Genetic similarity between hull-less and malting barley varieties revealed by UPGMA cluster analysis based on Jaccard similarity coefficient. Numbers within parentheses indicate the number of plants per variety. IACIBON 214/82 abbreviates as IACIB 214/82.

Table 2 - Total number of bands, polymorphic and intravarietal monomorphic bands, and size range of bands for each primer.

\begin{tabular}{|c|c|c|c|c|c|}
\hline Primer & $\begin{array}{c}\text { Primer } \\
\text { sequence }\left(5^{\prime}-3^{\prime}\right)\end{array}$ & $\begin{array}{c}\text { Total of } \\
\text { reproducible } \\
\text { bands }\end{array}$ & $\begin{array}{l}\text { Polymorphic } \\
\text { bands }\end{array}$ & $\begin{array}{c}\text { Intravarietal } \\
\text { monomorphic } \\
\text { bands }\end{array}$ & $\begin{array}{c}\text { Fragment size } \\
\text { ranges (bp) }\end{array}$ \\
\hline A01 & CAGGCCCTTC & 06 & 06 & 06 & $600-2300$ \\
\hline A02 & TGCCGAGCTG & 07 & 07 & 04 & $600-4400$ \\
\hline F03 & CCTGATCACC & 07 & 07 & 07 & $600-1400$ \\
\hline F05 & CCGAATTCCC & 02 & 02 & 02 & $900-1400$ \\
\hline F09 & CCAAGCTTCC & 12 & 12 & 12 & $300-2400$ \\
\hline Total & & 34 & 34 & 31 & $300-4400$ \\
\hline Mean/Primer & & 6.8 & 6.8 & 6.2 & - \\
\hline
\end{tabular}

Table 3 - Intravarietal genetic similarity estimated by Jaccard similarity coefficient.

\begin{tabular}{lccccc}
\hline Cultivar & Range & Average & Cultivar & Range & Average \\
\hline BR-2 & $0.65-1.00$ & 0.83 & HARRINGTON & $0.10-1.00$ & 0.54 \\
EMBRAPA 127 & $0.35-1.00$ & 0.61 & IAPAR 39 & $0.70-1.00$ & 0.82 \\
EMBRAPA 128 & $0.55-1.00$ & 0.80 & IAC 8501/22 & $0.70-1.00$ & 0.84 \\
CBB1 & $0.05-1.00$ & 0.53 & IAC 8501/31 & $0.70-1.00$ & 0.85 \\
BRS 195 & $0.15-1.00$ & 0.65 & IAC 8501/12 & $0.70-1.00$ & 0.85 \\
MN 684 & $0.30-1.00$ & 0.70 & IACIBON 214/82 & $0.20-1.00$ & 0.65 \\
MN 698 & $0.40-1.00$ & 0.68 & IAC 86012/421 & $0.70-1.00$ & 0.85 \\
\hline
\end{tabular}


larity coefficients (0.82-0.85), except IACIBON214/82 (0.65), and malting variety CBB 1 presented the lowest one (0.53). The occurrence of intravarietal variability in Brazilian barley varieties has been already observed by RAPD (Selbach \& Cavalli-Molina, 2000) and by hordein patterns (Echart-Almeida \& Cavalli-Molina, 2000). Selbach \& Cavalli-Molina (2000) proposed that genetic variability in the Brazilian varieties may be a consequence of thin selection imposed by breeders. These authors have reported a high degree of genetic relationship among different Brazilian malting varieties and a high degree of variability within them. Despite this high intravarietal variability, they demonstrated that plants of the same variety fell into a unique group and only later joined those of different varieties. We observed the same structure of variability among and within varieties.

Chemical characterization of the same six hullless barley varieties used in our study was performed by Helm \& de Francisco (2004), the authors found high $\beta$ glucan and protein content. Then, these varieties are more appropriate for health-promoting food products than to malting. Yu et al. (2002) proposed a specific RAPD fragment that differentiates high and low $\beta$-glucan content varieties. Further studies will be conducted to test a RAPD marker that could be used to select high and low $\beta$-glucan content varieties.

\section{CONCLUSIONS}

RAPD markers were suitable for detection of genetic variability between Brazilian barley varieties. Therefore, they can discriminate these varieties and can be used to assist in their identification.

\section{ACKNOWLEDGEMENTS}

This work was supported by FUNPESQUISA 2002 Universidade Federal de Santa Catarina. MAK and MSR were supported by fellowship from CAPES, CT was supported by IC fellowship from CNPq. We would like to express our gratitude to Karine Louise dos Santos for helpful assistance.

\section{REFERENCES}

BAUM, B.R.; MECHANDA, S.; SOLEIMANI, V. Identification of Canadian six row barley (Hordeum vulgare $\mathrm{L}$ ) cultivars with primers derived from STSs obtained from RAPD diagnostic bands. Seed Science and Technology, v.28, p.445-466, 2000.
BHATTY, R.S. The potential of hull-less barley. Cereal Chemistry, v.76, p.589-599, 1999.

BHATTY, R.S. ROSSNAGEL, B.G. Comparison of Pearled and Unpearled Canadian and Japanese Barleys. Cereal Chemistry, v.75, p.15-21, 1998.

CHEN, X.P.; YAN, L.; DING, Y. RAPD analysis and the probable evolutionary route of wild relatives of barley from China. Acta Botanica Sinica, v.42, p. 179-183, 2000.

DIAZ-PERALES, A.; LINACERO, R.; VÁZQUEZ, A.M. Analysis of genetic relationships among 22 European barley varieties base on two PCR markers. Euphytica, v.129, p.53-60, 2002.

DOYLE, J.J.; DOYLE, J.L. Isolation of plant DNA from fresh tissue. Focus v.12, p.13-15, 1990.

ECHART-ALMEIDA, C.; CAVALLI-MOLINA, S. Hordein variation in Brazilian barley varieties (Hordeum vulgare $L$.) and wild barley ( $H$. euclaston Steud. and H. stenostachys Godr.) Genetics and Molecular Biology, v.23, p.425-433, 2000.

FERNANDEZ, M.E.; FIGUEIRAS, A.M.; BENITO, C. The use of ISSR and RAPD markers for detecting DNA polymorphism, genotype identification and genetic diversity among barley cultivars with known origin. Theoretical and Applied Genetics, v.104, p.845-851, 2002.

GILL, S.; VASANTHAN, T.; OORAIKUL, B.; ROSSNAGEL, B. Wheat Bread Quality as Influenced by the Substitution of Waxy and Regular Barley Flours in Their Native and Extruded Forms. Journal of Cereal Science, v.36, p.219-237, 2002.

HANG, A.; BURTON, C.S.; HOFFMAN, D.L.; JONES, B.L. Random amplified polymorphic primer-generated embryo DNA polymorphisms among 16 North American malting barley cultivars. Journal of the American Society of Brewing Chemists, v.58, p.147-151, 2000.

HELM, C.V.; FRANCISCO, A. Chemical characterization of Brazilian hulless barley, flour fractionation, and protein concentration. Scientia Agricola, v.61, p.593-597, 2004.

MOLINA-CANO, J.-L.; FRANCESCH, M.; PEREZ-VENDRELL, A.M.; RAMO, T.; VOLTAS, J.; BRUFAU, J. Genetic and environmental variation in malting and feed quality of barley. Journal of Cereal Science, v.25, p.37-47, 1997.

ROHLF, F.J. NTSYS-pc: numerical taxonomy and multivariate analysis system. New York: Exeter Software, 1992.

SELBACH, A.; CAVALLI-MOLINA, S. RAPD characterization of Brazilian barley (Hordeum vulgare ssp vulgare) varieties. Euphytica, v.111, p.127-135, 2000.

TODOROVSKA, E.; TRIFONOVA, A.; ATANASSOV, A. Genetic diversity among elite Bulgarian barley varieties evaluated by RFLP and RAPD markers. Euphytica, v.129, p.325-336, 2003.

TSUCHIYA, Y.; ARAKI, S.; SAHARA, H.; TAKASHIO, M.; KOSHINO, S. Identification of malting barley varieties by genome analysis. Journal of Fermentation and Bioengineering, v.79, p.429-432, 1995.

YU, Z.; LI-QIONG, L.; HUAN, L.; JIE, B.; MAN-YE, Y.; CHEN, M.; YING-FAN, C.; XIAO-LIN, Q.; FANG, C. RAPD markers in diversity detection and variety identification of Tibetan Hulless Barley. Plant Molecular Biology Report, v.20, p.369-377, 2002.

YU, P.; MEIER, J.A.; CHISTENSEN, D.A.; ROSSNAGEL, B.G.; McKINNON, J.J. Using the NRC-2001 model and the DVE/OEB system to evaluate nutritive values of Harrington (malting-type) and Valier (feedtype) barley for ruminants. Animal Feed Science and Technology, v.107, p.45-60, 2003

(Endnotes)

Received February 09, 2004

Accepted November 04, 2004 